\title{
EFFECT OF SIMVASTATIN ON HISTOPATHOLOGY OF THE HEART AFTER 5/6 SUBTOTAL NEPHRECTOMY
}

\author{
PUTU NITA CAHYAWATI* \\ Department of Pharmacology and Pharmacy, Faculty of Medicine and Health Sciences, Warmadewa University, \\ Bali, Indonesia. Email: putunitacahyawati@gmail.com
}

Received: May 6, 2019, Revised and Accepted: July 20, 2019

\section{ABSTRACT}

Objective: This study aims to assess the condition of cardiac histopathology through hematoxylin-eosin staining in $5 / 6$ subtotal nephrectomy conditions.

Methods: Fifteen male Swiss mice aged 3-5 months will be grouped into 3 treatment groups, namely the nephrectomy group (JSN, n=5), sham operation (JSO, n=5), and simvastatin $20 \mathrm{mg} / \mathrm{kg}$ body weight (JSIM, n=5). The histopathology of the heart will be assessed blindly. Severity is assessed based on scoring using a scale $(-)$ no damage, $(+)$ mild, $(++)$ medium, and $(+++)$ heavy. Assessment of severity refers to the irregularity of the heart muscle, increased amount of connective tissue, myofibril hypertrophy, myofibril swelling, sarcoplasmic fragmentation, sarcoplasmic vacuolization, bleeding in a myofibril, myofibril degeneration, cardiomyocyte damage, and the presence of acidophilic cytoplasm.

Results: The results showed no morphological changes in heart muscle tissue in the JSO group except for fragmentation and vacuolization in minimal amounts of sarcoplasm (+), whereas in the JSN and JSIM groups, there was moderate damage to sarcoplasm (++) and minimal changes in myofibrils (hypertrophy and bleeding) (+). The JSN group also found severe damage $(+++)$ to the irregularity of the heart muscle, whereas in JSIM, only moderate damage was found $(++)$ to the irregularity of the heart muscle.

Conclusion: Simvastatin seems to be able to correct the irregularity of the heart muscle in the condition of $5 / 6$ subtotal nephrectomy.

Keywords: Cardiac histopathology, Subtotal 5/6 nephrectomy, Simvastatin, Myofibrils.

(C) 2019 The Authors. Published by Innovare Academic Sciences Pvt Ltd. This is an open access article under the CC BY license (http://creativecommons. org/licenses/by/4. 0/) DOI: http://dx.doi.org/10.22159/ijap.2019.v11s5.T0105

\section{INTRODUCTION}

Cardiovascular disease is a condition that often occurs in patients with chronic renal failure (CRF). This condition increases the risk of death in patients. The prevalence of this disease also increases with increasing severity of kidney function [1-3]. The cardiovascular events that often occur are heart failure. This disease is estimated to have affected 23 million world populations, where the prevalence was higher in CRF patients than without CRF $(63 \%$ vs. $5.8 \%)$ [3-5]. In the United States, this disease is the main cause of hospitalization [6].

Statins are very potent 3-hydroxy-3-methyl-3-methylglutarylcoenzyme A reductase inhibitors. Besides its ability to inhibit cholesterol biosynthesis and reduce serum levels of low-density lipoprotein (LDL) cholesterol, statins have also been reported to have pleiotropic effects such as anti-inflammatory, antioxidants and improve endothelial function and angiogenesis. Statins are widely used in chronic ischemic heart disease and show improvement in endothelial function through increased production of endogenous nitric oxide, C-reactive protein, oxidized LDL, and cytokines such as tumor necrosis factor $\alpha$ and interleukin-6 [7].

Heart failure is characterized by systemic and vascular inflammation characterized by an increase in inflammatory biomarker and adhesion molecules [6]. The previous study shows that simvastatin therapy for 14 days was able to improve the fibrosis condition. However, the exact mechanism is not yet known [8]. For this reason, further research is needed to assess the condition of heart histopathology in more detail. This study aims to determine the histopathology of the heart in the CRF condition using animal models.

\section{METHODS}

\section{Drug}

Simvastatin (Sigma-Aldrich, Singapore) was dissolved in a 1\% solution of carboxymethyl cellulose (CMC) (Sigma-Aldrich, St Louis, USA). Simvastatin is given orally once a day for 14 days.

\section{Animals}

In this study, eighteen male Swiss mice with weighing 30-40 g were purchased from the experimental animal research center, Universitas Udayana, Denpasar. All mice were housed according to the treatment group at room temperature about $22 \pm 2^{\circ} \mathrm{C}$ and humidity about $50 \pm 5 \%$ with a $12-12$ h light-dark cycle. They had free access to tap water and about 3-5 g standard food per day. This study was approved by Komite Etik Penelitian Fakultas Kedokteran Universitas Udayana/Rumah Sakit Umum Pusat Sanglah Denpasar No: 2125/UN14.2.2.VII.14/LP/2018.

\section{Experimental protocol}

All mice were randomized and acclimatized for 7 days. The mice were grounded according to the treatment group. Mice were divided in three groups $(n=6)$ including sham group (JSO, group with only incision on the both sides of the flank region but there is no intervention on the kidney and 1\% CMC solution), 5/6 subtotal nephrectomy group (JSN, group with nephrectomy on right kidney and ablation on superior and inferior part of the left kidney and simvastatin $20 \mathrm{mg} / \mathrm{kg}$ body weight [BW]), and simvastatin group (JSIM, group with 5/6 subtotal nephrectomy group and simvastatin $20 \mathrm{mg} / \mathrm{kg} \mathrm{BW})[9,10]$. Animals were anesthetized using a combination of ketamine $(90 \mathrm{mg} / \mathrm{kg} \mathrm{BW})$ and xylazine $(10 \mathrm{mg} / \mathrm{kb} \mathrm{BW})$ through intraperitoneal injection. At the end of the study, the hearts were obtained from all the animals. 
Histopathological assessment

For histopathological analyses, isolated hearts fixed in 10\% buffer formalin. The samples dehydrated with ethanol and embedded in paraffin. Sections with $4 \mu \mathrm{m}$ thickness were cut and stained with hematoxylin-eosin (HE). Cardiac histopathology analysis includes cardiac muscle regularity, increased connective tissue, myofibril hypertrophy, swelling, sarcoplasmic fragmentation and vacuolization, bleeding and degeneration of myofibrils, cardiomyocyte damage, and the presence or absence of acidophilic cytoplasm. Assessment is based on observations of 10 view fields with $\times 400$ magnification. Histological changes scored on a 4-point scale: $(-)$ none, $(+)$ mild, $(++)$ moderate, and $(+++)$ severe damage [11]. The morphological measurement was
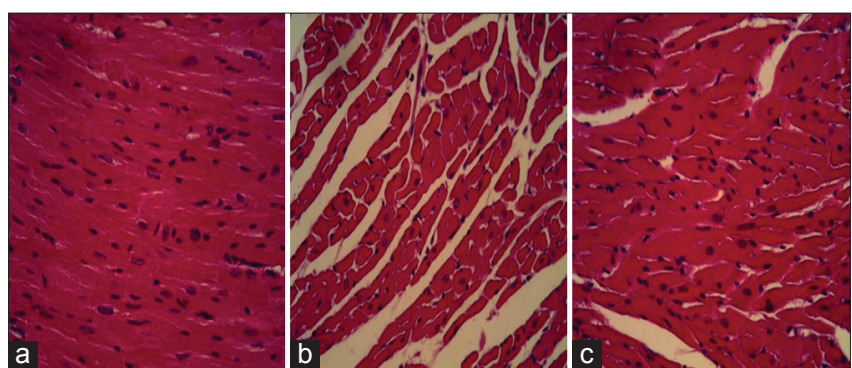

Fig. 1: Cardiac histopathology on each group with hematoxylineosin staining, (a) JSO group, (b) JSN group, (c) JSIM group.

Magnification $\times 400$ performed blindly. Furthermore, we analyze semi-quantitatively by giving a score of $0-3$ based on the average point of scale obtained $(0=0-0.5 ; 1 \geq 0.5-1.5 ; 2 \geq 1.5-2.5 ; 3 \geq 2.5)$

\section{Statistical analyses}

We used the SPSS 18.0 software for data processing. The results were expressed as the mean \pm standard deviation. The results were analyzed by one-way ANOVA followed by Tukey test for data that normally distributed and Mann-Whitney test for data that not normally distributed. $\mathrm{p}<0.05$ was considered statistically significant.

\section{RESULTS AND DISCUSSION}

The results of this study showed that there were no morphological changes in the heart muscle tissue in the JSO group except for slight fragmentation and vacuolization of sarcoplasm. Whereas in the JSN and JSIM groups, there were moderate damage to sarcoplasm (++) and minimal changes in myofibrils (hypertrophy and bleeding) $(+)$. The JSN group also found severe damage $(+++)$ on the heart muscle, whereas JSIM found only moderate damage (++) (Table 1 and Fig. 1).

Based on the results of the average total point of the scale, it was found that there were significant differences in cardiac muscle irregularities between JSO versus JSN groups $(0.20 \pm 0.27$ vs. $2.27 \pm 0.46), p=0.00$ and JSO versus JSIM ( $0.20 \pm 0.27$ vs. $1.75 \pm 0.51)$, $\mathrm{p}=0.00$. However, there was no significant difference between the

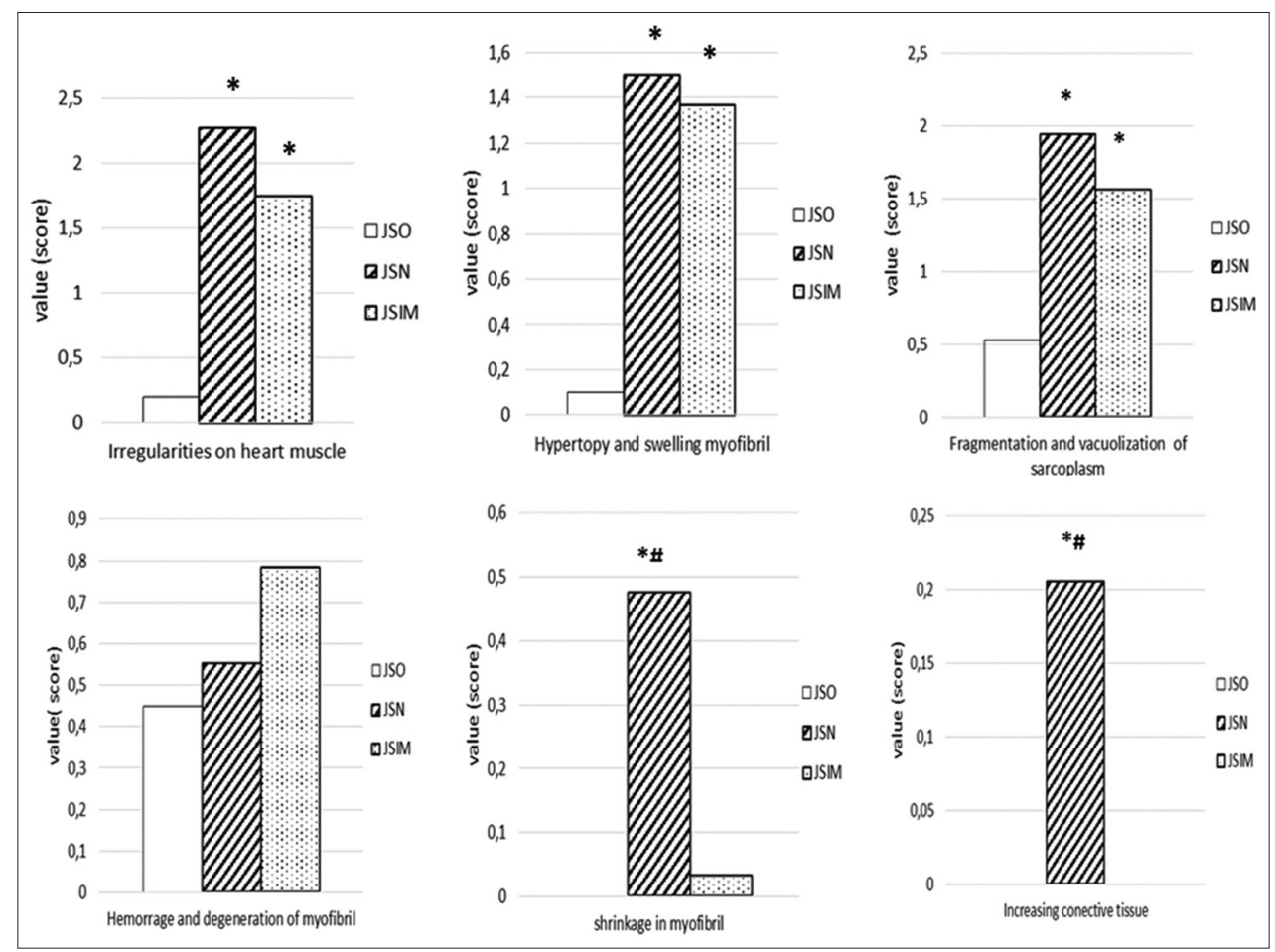

Fig. 2: Semiquantitative histological changes in the heart in each group. *Versus JSO, \#versus JSIM

Table 1: Histological changes in the heart in each group (HE staining)

\begin{tabular}{|c|c|c|c|c|c|c|}
\hline Groups & $\begin{array}{l}\text { Irregularities } \\
\text { on heart } \\
\text { muscle }^{\mathrm{a}}\end{array}$ & $\begin{array}{l}\text { Hypertrophy } \\
\text { and swelling } \\
\text { myofibril }^{\mathrm{a}}\end{array}$ & $\begin{array}{l}\text { Fragmentation } \\
\text { and vacuolization } \\
\text { of sarcoplasm }^{\mathrm{a}}\end{array}$ & $\begin{array}{l}\text { Hemorrhage and } \\
\text { degeneration of } \\
\text { myofibril }^{\mathrm{a}}\end{array}$ & $\begin{array}{l}\text { shrinkage in } \\
\text { myofibril }^{\text {a }}\end{array}$ & $\begin{array}{l}\text { Increasing } \\
\text { connective tissue }\end{array}$ \\
\hline JSO & - & - & + & - & - & - \\
\hline JSN & +++ & + & ++ & + & - & - \\
\hline JSIM & ++ & + & ++ & + & - & - \\
\hline
\end{tabular}

aScale: $(-)$ none, $(+)$ mild, $(++)$ moderate, $(+++)$ severe damage. HE: Hematoxylin-eosin 
JSN versus JSIM group, $\mathrm{p}=0.11$. Similar results were also found in hypertrophy and swelling myofibril conditions. There were significant differences between JSO versus JSN groups $(0.10 \pm 0.24$ vs. $1.49 \pm 0.42), p=0.00$ and JSO versus JSIM $(0.10 \pm 0.24$ vs. $1.37 \pm 0.45)$, $\mathrm{p}=0.00$. However, there was no significant difference between the JSN versus JSIM groups, $\mathrm{p}=0.82$. The assessment of sarcoplasm fragmentation and vacuolization also found similar data. There was a significant difference between JSO versus JSN group ( $0.53 \pm 0.29$ vs. $1.95 \pm 0.81), p=0.00$ and JSO versus JSIM ( $0.53 \pm 0.29$ vs. $1.57 \pm 0.52)$, $\mathrm{p}=0.02$. However, there was no significant difference between JSN versus JSIM groups, $p=0.53$. There was no significant difference in the signs of hemorrhage and degeneration of myofibril in the treatment group ( $\mathrm{p}=0.15)$. The analysis using Mann-Whitney test on the signs of shrinkage in myofibril and increasing connective tissue has significant differences in the JSO versus JSN and JSN versus JSIM groups, p $<0.05$ (Fig. 2).

Myocardial reactions to injury are more limited than many other tissues. Injury on myofibers is irreversible. The necrotic debris due to injury will be phagocytized and replaced by fibrous tissue. The uremic toxin has been demonstrated in vitro as a contributory factor in cardiac fibrosis and makes typical structural changes, "uremic cardiomyopathy" [12]. Based on the results of the cardiac biopsy in CRF patients, there is a change in the myocardial structure such as cardiomyocyte hypertrophy and myocardial fibrosis, as well as thickening of the arterial walls and arterioles. The fibrosis conditions mainly occur due to an imbalance of synthesis and degradation of collagen, in addition to the contribution of other factors such as excess fluid, inflammatory processes, oxidative stress, or due to worsening of the patient's condition in CRF $[12,13]$. Treatment with a statin on CRF model seems able to decrease of vascular wall thickness significantly compared with the nephrectomy group [8]. This is possible because statins are known to have the ability to reduce oxidative stress and transforming growth factor beta (pro-inflammatory cytokines) and inhibit angiotensin II/Smad pathways $[14,15]$.

In this study, fibrosis has not occurred in all treatment groups. The changes that occur are in the form of hypertrophy in the heart muscle. In general, pathological cardiac hypertrophy characterized by the thickening of the heart muscle, a decrease in the size of the chambers of the heart, and a reduced capacity of the heart to pump blood to the tissues and organs around the body [16].

\section{CONCLUSION}

The most prominent change in histopathology myocardium on the JSN group is the irregularity of the heart muscle. The administration of simvastatin seems to be able to correct the irregularity of the heart muscle but not statistically significant. The possibility of increasing the dose may have a better effect. However, the exact mechanism of the occurrence of this condition is not fully understood, so further research is still needed.

\section{CONFLICTS OF INTEREST}

There is no conflict of interest related to this research. This study financially supported by the Faculty of Medicine and Health Sciences, Warmadewa University, Bali, Indonesia.

\section{REFERENCES}

1. Foster MC, Rawlings AM, Marrett E, Neff D, Willis K, Inker LA, et al. Cardiovascular risk factor burden, treatment, and control among adults with chronic kidney disease in the United States. Am Heart J 2013;166:150-6

2. Bagshaw SM, Cruz DN, Aspromonte N, Daliento L, Ronco F, Sheinfeld G, et al. Epidemiology of cardio-renal syndromes: Workgroup statements from the $7^{\text {th }}$ ADQI consensus conference. Nephrol Dial Transplant 2010;25:1406-16.

3. Quarles LD. Reducing cardiovascular mortality in chronic kidney disease: Something borrowed, something new. J Clin Invest 2013;123:542-3.

4. Pecoits-Filho R, Bucharles S, Barberato SH. Diastolic heart failure in dialysis patients: Mechanisms, diagnostic approach, and treatment. Semin Dial 2012;25:35-41.

5. U.S. Renal Data System (USRDS). Chronic Kidney Disease in the Adult NHANES Population. USRDS Annual Report Data; 2009. Available from: http://www.usrds.org/USRDS/pdf/V1 01 09.PDF. [Last accessed on 2019 Mar 25].

6. Deedwania PC, Javed U. Statins in heart failure. Cardiol Clin 2008;26:573-87.

7. Miura S, Saku K. Effects of statin and lipoprotein metabolism in heart failure. J Cardiol 2010;55:287-90.

8. Cahyawati PN, Arfian N, Ngatidjan N. Effect of statin on vascular wall thickness in kidney disease model. IOP Conf Ser Mater Sci Eng 2018;434:012324

9. Cahyawati PN, Ngatidjan N, Sari DC, Romi MM, Arfian N. Simvastatin attenuates renal failure in mice with a 5/6 subtotal nephrectomy. Int J Pharm Pharm Sci 2017;9:12-7.

10. Cahyawati PN, Aryastuti AA, Ariawan MB, Arfian N, Ngatidjan N. Statin and Anemia in Chronic Kidney Disease (CKD): An Experimental Study. MATEC Web of Conferences 197; 2018.

11. Alihemmati A, Yousefi H, Ahmadiasi N, Habibi P. Apoptosis and histopatology of the heart after renal ischemia-reperfusion in male rat running title: Ischemia-reperfusion injury. Braz Arch Biol Thechnol 2017;60:e17160244

12. Lekawanvijit S, Kompa AR, Manabe M, Wang BH, Langham RG, Nishijima F, et al. Chronic kidney disease-induced cardiac fibrosis is ameliorated by reducing circulating levels of a non-dialysable uremic toxin, indoxyl sulfate. PLoS One 2012;7:e41281.

13. López B, González A, Hermida N, Laviades C, Díez J. Myocardial fibrosis in chronic kidney disease: Potential benefits of torasemide. Kidney Int Suppl 2008;111:S19-23.

14. Rodrigues Díez R, Rodrigues-Díez R, Lavoz C, Rayego-Mateos S, Civantos E, Rodríguez-Vita J, et al. Statins inhibit angiotensin II/Smad pathway and related vascular fibrosis, by a TGF- $\beta$-independent process. PLoS One 2010;5:e14145.

15. Zhou MS, Schuman IH, Jaimes EA, Raij L. Renoprotection by statins is linked to a decrease in renal oxidative stress, TGF-beta, and fibronectin with concomitant increase in nitric oxide bioavailability. Am J Physiol Renal Physiol 2008;295:F53-9.

16. Kavazis AN. Pathological vs. Physiological cardiac hypertrophy. J Physiol 2015;593:3767 